Report of Investigation 2020-2A

REGIONAL TSUNAMI HAZARD ASSESSMENT FOR THE COMMUNITIES OF KASAAN, KLAWOCK, METLAKATLA, PELICAN, POINT BAKER, AND PORT PROTECTION IN SOUTHEAST ALASKA

\title{
ADDENDUM A: REGIONAL TSUNAMI HAZARD ASSESSMENT FOR HYDABURG, ALASKA
}

E.N. Suleimani, D.J. Nicolsky, J.B. Salisbury, and M.E. West

Published by

STATE OF ALASKA

DEPARTMENT OF NATURAL RESOURCES

DIVISION OF GEOLOGICAL \& GEOPHYSICAL SURVEYS

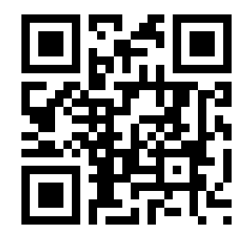




\section{STATE OF ALASKA}

Mike Dunleavy, Governor

\section{DEPARTMENT OF NATURAL RESOURCES}

Corri A. Feige, Commissioner

\section{DIVISION OF GEOLOGICAL \& GEOPHYSICAL SURVEYS}

Steve Masterman, State Geologist and Director

Publications produced by the Division of Geological \& Geophysical Surveys (DGGS) are available for free download from the DGGS website (dggs.alaska.gov). Publications on hard-copy or digital media can be examined or purchased in the Fairbanks office:

Alaska Division of Geological \& Geophysical Surveys 3354 College Rd., Fairbanks, Alaska 99709-3707

Phone: (907) 451-5010 Fax (907) 451-5050

dggspubs@alaska.gov|dggs.alaska.gov

\section{DGGS publications are also available at:}

Alaska State Library,

Historical Collections \& Talking Book Center

395 Whittier Street

Juneau, Alaska 99811

Alaska Resource Library and Information Services (ARLIS)

3150 C Street, Suite 100

Anchorage, Alaska 99503

\section{Suggested citation:}

Suleimani, E.N., Nicolsky, D.J., Salisbury, J.B., and West, M.E., 2020, Addendum A: Regional tsunami hazard assessment for Hydaburg, Alaska, in Suleimani, E.N., Nicolsky, D.J., Salisbury, J.B., and West, M.E., Regional tsunami hazard assessment for the communities of Kasaan, Klawock, Metlakatla, Pelican, Point Baker, and Port Protection in Southeast Alaska: Alaska Division of Geological \& Geophysical Surveys Report of Investigation 2020-2A, 3 p., 1 sheet. http://doi.org/10.14509/30438
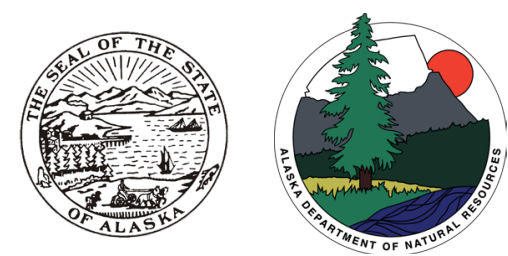


\title{
ADDENDUM A: REGIONAL TSUNAMI HAZARD ASSESSMENT FOR HYDABURG, ALASKA
}

\author{
E.N. Suleimani, D.J. Nicolsky, J.B. Salisbury, and M.E. West
}

Immediately prior to publication of our regional tsunami assessment for selected communities in southeast Alaska (Suleimani and others, 2020), the community of Hydaburg requested we conduct a tsunami hazard assessment for their city. This addendum to that report contains regional tsunami hazard modeling results for Hydaburg, a native community of 398 people located on the southwest coast of Prince of Wales Island, 45 air miles northwest of Ketchikan (fig. 2A of the main report).

The following information is extracted from the Alaska Community Database Online provided by the State of Alaska Division of Community and Regional Affairs (dcced.maps.arcgis.com/ apps/MapJournal/index.html ? appid $=69727 \mathrm{f}$ dd3c844f48baec7cb76b99938a\#). During the mid to late 1700s, the Haidas migrated to Prince of Wales Island, a predominantly Tlingit area, from Graham Island in the Queen Charlotte Islands, Canada. Hydaburg was incorporated as a city in 1927, three years after its people had become citizens of the United States. The first fish processing plant opened in 1927, and three other canneries operated through the 1930s. When the Indian Reorganization Act (IRA) was amended in 1936 to include Alaska Natives, Hydaburg became the first village in Alaska to form an IRA council. Today Hydaburg is the largest Haida community in Alaska. Residents maintain a subsistence and commercial fishing lifestyle.

We performed numerical calculations for all four tsunami sources described in the main report (fig. 4). For each tsunami source, we modeled the water dynamics in each grid listed in table 2 of the main report and computed maximum tsunami wave heights in the level 3 grid that covers the community of Hydaburg. Each model run was performed for 24 hours of tsunami propagation to account for all waves in the wave train, as well as for secondary (reflected) waves. Figure 6 in the main report shows the maximum composite tsunami heights for all scenarios in the level 3 grids for Prince of Wales Island. Typically, tsunami amplitudes are much higher on the Pacific coast than on the east coast of the island along the Clarence Strait. However, Dall and Suemez islands are west of Hydaburg and therefore the community is better protected from tectonic tsunamis than Klawock, Point Baker, and Port Protection, also located on the Pacific coast of the island.

Figure A1 shows the maximum composite tsunami height for all scenarios, calculated in the vicinity of Hydaburg. The absolute maximum value of the tsunami height, multiplied by a safety factor of 1.3 , results in a maximum assumed runup height of $1.6 \mathrm{~m}(5.3 \mathrm{ft})$. We project the value of maximum assumed runup height on land by drawing an elevation contour on the community topographic map that corresponds to this height. This contour approximates the boundary of the tsunami hazard zone and could be used by emergency planners and public officials as a guideline in tsunami mitigation activities. Map sheet A1 shows the maximum composite calculated extent of inundation and the maximum composite flow depths over dry land in Hydaburg.

\footnotetext{
${ }^{1}$ Alaska Earthquake Center, Geophysical Institute, University of Alaska, P.O. Box 757320, Fairbanks, Alaska 99775-7320; ensuleimani@alaska.edu

${ }^{2}$ Alaska Division of Geological \& Geophysical Surveys, 3354 College Rd., Fairbanks, Alaska 99709-3707.
} 


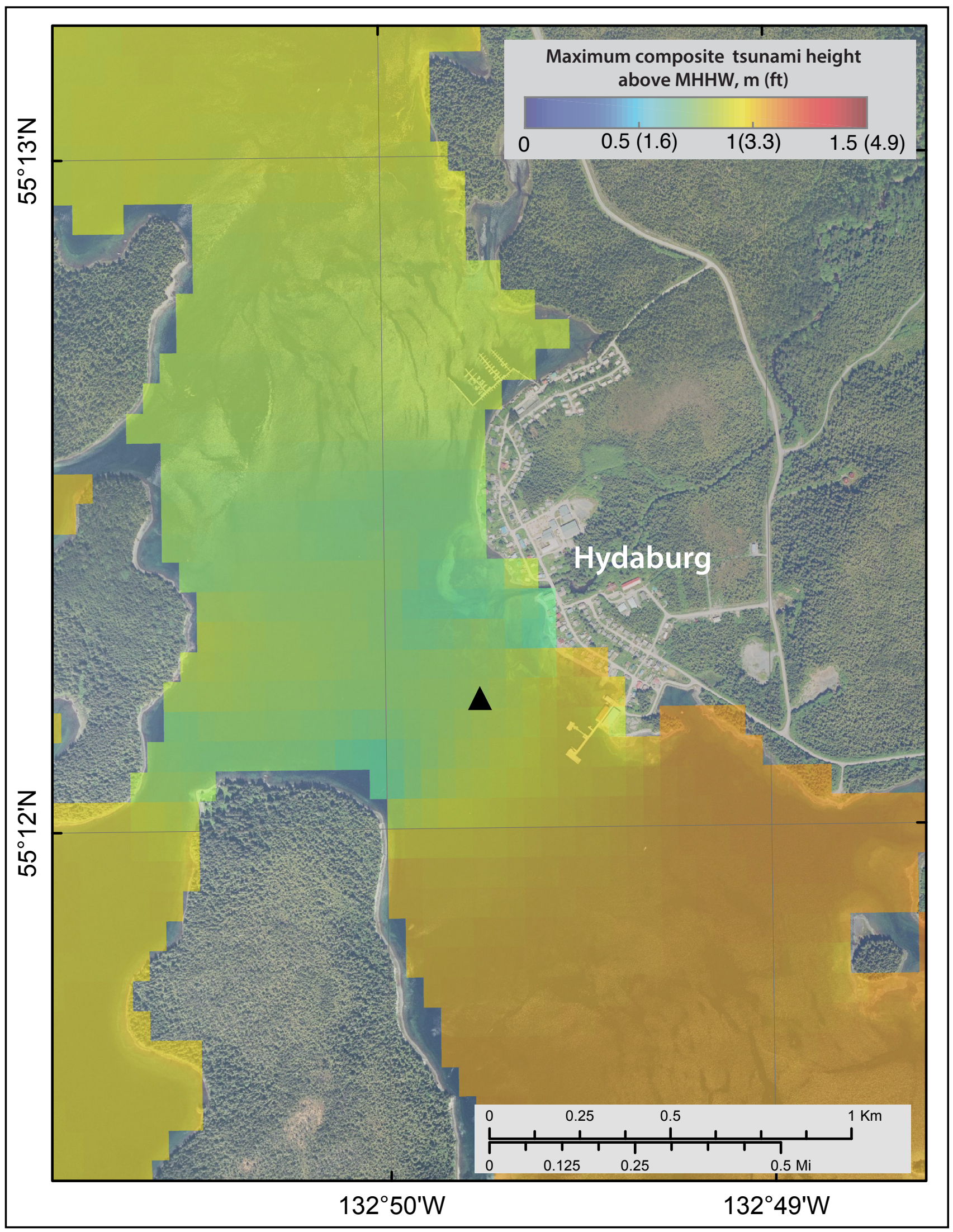

Figure A1. Maximum composite tsunami height at Hydaburg. The black triangle indicates the location of the time series shown in figure $\mathrm{A} 2$. 


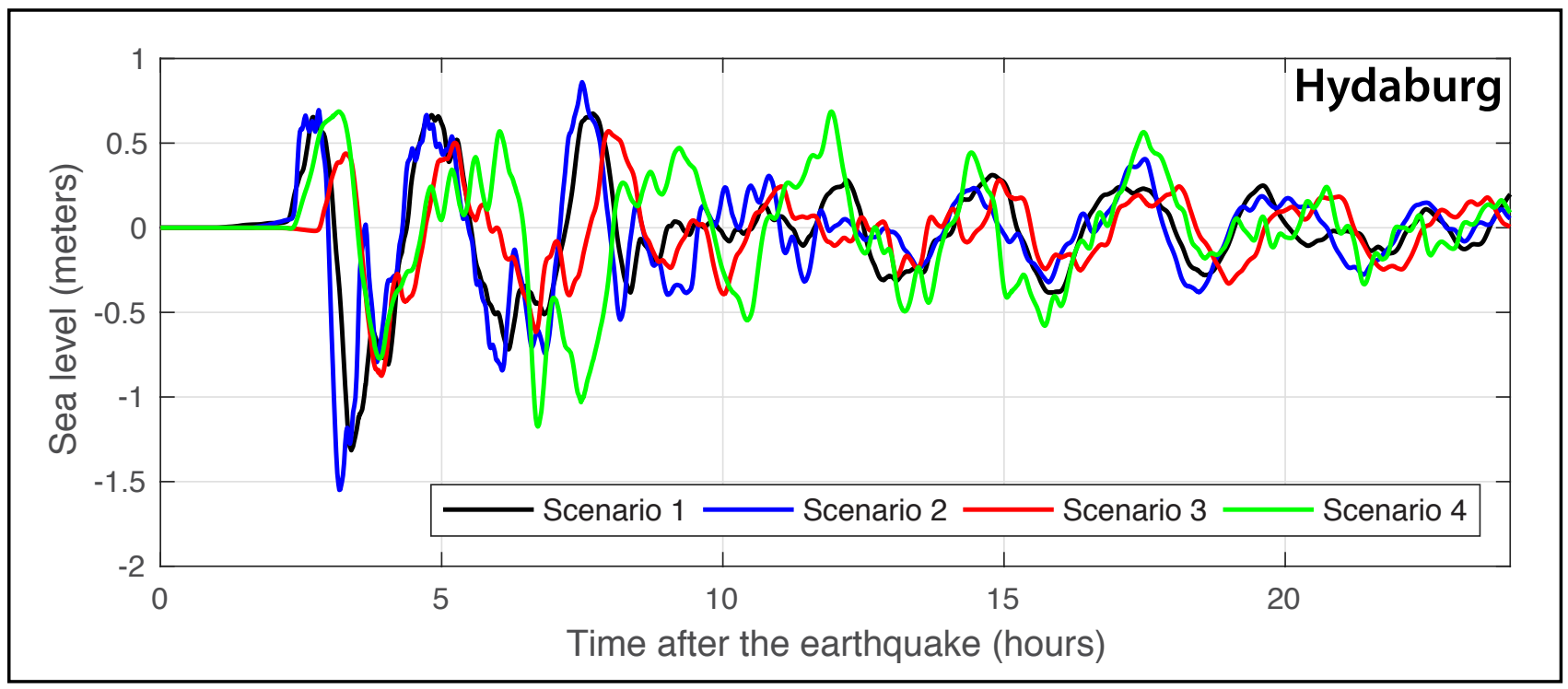

Figure A2. Time series of water level for scenarios 1-4 at Hydaburg, calculated at the location of the black triangle in figure A1.

Figure A 2 shows the time series of the modeled water level off the coast of Hydaburg (exact location indicated by a black triangle in figure A1). The plot begins with the occurrence of the earthquake (time $=0)$. Analysis of the time series plots shows that the first wave has about the same amplitude for scenarios 1, 2, and 4, and scenario 3 results in a smaller first wave. The overall largest wave, which is the third wave arriving about 7.5 hours after the earthquake, corresponds to scenario 2 , a hypothetical earthquake in the 1964 rupture area with Tohoku-type slip distribution. While the amplitudes of the waves corresponding to scenarios
1-3 decrease after about 8 hours, the waves corresponding to scenario 4 , the rupture of the Cascadia subduction zone, maintain their initial energy for almost 18 hours after the earthquake.

\section{REFERENCES}

Suleimani, E.N., Nicolsky, D.J., Salisbury, J.B., and West, M.E., 2020, Regional tsunami hazard assessment for the communities of Kasaan, Klawock, Metlakatla, Pelican, Point Baker, and Port Protection in Southeast Alaska: Alaska Division of Geological \& Geophysical Surveys Report of Investigation 2020-2, 24 p., 6 sheets. http://doi.org/10.14509/30423 